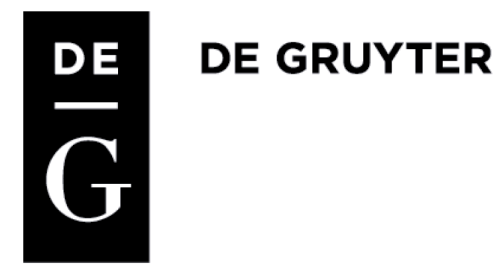

\title{
FINANCIAL CRIME IN CRIME FICTION IN SOCIALIST POLAND
}

Financial crime was one of the recurring themes in crime stories written in the period of socialist Poland. The writer who first undertook this subject was Leopold Tyrmand in his book "The Man with the White Eyes" (1955). The publication of this book is considered one of the symptoms of the cultural "thaw" and the end of real socialism. Tyrmand shows crime which develops when the state, cooperative and private businesses meet, but also the corruption and powerlessness of Citizen's Militia. During Wtadystaw Gomutka's administration (1956-1970), this problem often recurred e.g. in the books written by Anna Kłodzinska and Barbara Gordon. Very often the villain was the "fraudulent director". Both the meat scandal and the leather scandal were described in crime novels. Edward Gierek's administration (1970-1980) was the time when the theme of financial crime was abandoned, but it returned after the introduction of martial law in 1981. This time, it was pointed out that it was the previous administration that had committed frauds. Crime novels accurately described the economic abnormalities of socialist Poland, the hampering of individual initiatives and the omnipresent corruption, but they also reflected the state's policy towards the people in power who were illegally gaining wealth.

Keywords: crime novel, socialist Poland, financial crime.

doi:10.1515/sho-2016-0003

\section{INTRODUCTION}

Crime novel (but also crime film) is a genre created with large audience in mind, whose primary purpose, by definition, is to entertain. Crime story is supposed to provide intellectual entertainment, but this does not mean that it has to be banal, silly or poorly written. However, if a crime author wants to sell, they must take the tastes of readers into consideration. In socialist Poland, the situation in this respect was quite unique. It was the 
time of never-ending shortages on the market, including the publishing market. This means products of poor quality were also bought. On the other hand, bad authors who were "ideologically right" could expect to be published. Whichever way we look, crime fiction remains a specific record of life back then. As it is often the case with entertainment genres, it referred to the surrounding reality and was often based on actual events. It had to comply with the idealogical requirements, but it was not created in a vacuum. It described - in a better or worse form, but still - the reality of socialist Poland. If one ignores its ideological coating, which in many cases was not even that brazen, one might learn a lot about these times.

The subject of this article is mainly crime novels from the socialist period in Poland. However, crime films will also be mentioned, many of which were adapted from books, or based on screenplays written by novelists. This is completely normal, anyway, and by no means characteristic for the entertainment business of socialist democracies. It is worth noting here that literature clearly dominated - in the investigated period, around 2,000 crime novels by Polish authors were published. This means that there were ten times more books than cinema and television films combined. If one looks at sales figures (between 30,000 to 240,000 copies per novel), crime fiction of the time can be considered mass-scale entertainment.

\section{POLISH CRIME FICTION IN GOMUŁKA PERIOD}

In the post-war period both Polish and foreign crime fiction authors were published in Poland. However, in the late 1940s this genre began to be considered a creation of the "rotten" bourgeoisie culture and of the capitalist society, and therefore condemned. Books were withdrawn from libraries, some of them were destroyed. This situation changed in the mid1950s, when the cultural "thaw" began [Skotarczak D. 2015: 27-36]. The book that shook the publishing market back then was "The Man with the White Eyes" by Leopol Tyrmand. Published in the beginning of 1955, it immediately became a bestseller and was sold-out. In the following year, it became the subject of debate, gaining supporters as well as opponents who accused Tyrmand of portraying the world as gloomy, Militia as powerless and the socialist reality - as not too appealing in general [Fik M. 1989: 234; "Radio i Świat" 1956: 13]. The debate on this book is evidence of its importance. But indeed, this was in many ways an extraordinary book. 
Tyrmand, along with Andrzej Piwowarczyk, became one of the fathers of the Polish crime novel in the socialist period. He also influenced its further development over the next few decades by providing a model of what should be shown and how.

But "The Man..." is also extremely interesting from the point of view of this article. Tyrmand described in detail the activities of the "Vanity Bag" cooperative, which, in the guise of a legal company, actually runs a financially criminal business. The president of the cooperative, Philip Merynos, controls e.g. illegal trade of cinema and sports event tickets (a network of the so-called scalpers). It is a very lucrative business and requires special "connections", owing to which Merynos manges to get hold of the tickets. These "connections" involve bribing public officials who organize ticket sales, so that thousands are delivered to the "Vanity Bag" cooperative instead of regular ticket offices. This is therefore an example of crime committed at the intersection between state, cooperative and private businesses. All this is accompanied by corruption and banditry. Citizens' Militia is completely powerless here, and the case is ultimately solved by a mysterious vigilante with the help of regular citizens. Tyrmand was accused of presenting a very depressing picture of socialist Poland. He responded by saying that the book is set right after the war ["Radio i Świat" 1956: 13].

The time of Władysław Gomułka administration (1956-1970) was the time of widespread fight against financial crime. Sentences were severe, often issued in the so-called emergency mode trials. This meant that financial crime was punishable even by death. The most notorious, legendary criminal case from the 1960s is the so-called "meat swindle" in which a death sentence was indeed administered [Jarosz D., Pasztor M. 2004: 9597]. However, corruption, fraud and theft were the subject of interest even earlier, starting from "The Man with the White Eyes". It seems that Polish crime novel was a part of the cultural "thaw" which occurred in the second half of the 1950s - it gave a very gloomy picture of the world and described depravity in state companies, cronyism, and botchery. Sometimes, in its brutality it was reminiscent of the articles and letters published in the middle of the decade in the "Po prostu" magazine [Leszczyński A. 2000: 25-84].

The most interesting novels describing the problem of financial crime were written by a journalist, Anna Kłodzińska: "Złota bransoleta" [The Golden Bracelet] (1958) and "Malwersanci" [Frauds] (1961, published in the "Kurier Polski" magazine). We can also mention "Ruda model- 
ka" [The Ginger Model] (1959) and "Nieznajomy z baru Calypso" (The Stranger from the Calypso Bar] (1959) by Damian Dominiak (pen-name of Adam Bahdaj), and "Pistolet z perłową rękojeścią" [The Gun with the Pearl Handle] by Arkadiusz Belin (1959, published in the "Kurier Polski" magazine). In the 1960s, the following notable books were published: "Klika" [Clique] (1964) and "Dwaj panowie w Zodiaku" [Two Men in the Zodiak] (1967) by Barbara Gordon (pen-name of Larysa ZajączkowskaMitzner), "Bardzo dużo pajacyków" [A Lot of Puppets] (1968) by Andrzej Zbych (pen-name of Zbigniew Safjan and Andrzej Szypulski), "Śmierć i Kowalski" [Death and Kowalski] (1962) by Kazimierz Kwaśniewski (penname of Maciej Słomczyński), "Czek dla białego gangu" [A Check for the White Gang] (1963) by Jerzy Edigey (pen-name of Jerzy Korycki).

In all the books, but particularly in those written in the 1950s, the life of Poles is depicted in a very depressing way. Poverty is ubiquitous, salaries are insufficient to make ends meet, and there is no entertainment whatsoever (e.g. "The Man...", “The Ginger Model”). And this - as Anna Kłodzińska points out - was the main reason why many people in Poland decided to commit crimes. In one book, we meet a wife of a public officer, who spends her holidays picking mushrooms so that she can afford two new towels. And it is just that - there is no money left to buy new bed linen. The living conditions of an average family portrayed in "Frauds" seem shocking but this was how - as Kłodzińska suggests - most people in Poland lived at the time. Another problem is the fact that there were usually four people in the family, while the husband was the sole breadwinner. At present, one salary of a state officer would probably not allow for much more, either. Whichever way we look at it, the Wilczyńskis from "Frauds" barely make ends meet and their prospects for the future are not too optimistic, unless the wife manages to find a decent job. As a last resort, the husband decides to make some money "on the side", enters into a criminal agreement with a clique operating in the plant, becomes its member and starts making decent money. Of course, "Frauds" ends in the same way as any other similar book - the Citizens' Militia finally catches the corrupt employees, while some of them cannot take the pressure even earlier and decide take their own lives. Books by Anna Kłodzińska point to the social consequences of the widespread depravity - the Wilczyński family falls apart, while the husband drowns his sorrows in alcohol and hedonism.

But the books by Kłodzińska, Gordon or Kwaśniewski also offer an interesting diagnosis, maybe even against the authors' will. All those books lead to a single conclusion - that it is impossible to make money legal- 
ly in Poland. In state companies, all initiatives are blocked, and talent and resourcefulness are oppressed. Employees are also paid very poorly, as salaries are "flattened". This means that although, naturally, the director makes more money than an average worker or a public officer, their salary is not that much higher in relative terms. It does not allow for any luxuries - honest directors in socialist Poland live in regular flats and very often cannot even afford to buy a car. And in many cases these are very energetic people with innovative ideas and a talent for trade. Unfortunately, this means nothing. Their talents are effectively oppressed and the difference between their social position and their capabilities is unbearable. This is the critical moment at which those directors or presidents decide to make some extra cash "on the side". The socialist state expects its officers to work for ideas, it does not take individual aspirations into consideration and this, as we learn from the novels, usually ends badly.

On the other hand, sometimes families of the new directors pressurize them, frustrated that despite high social position of the father/husband they cannot afford holidays in socialist democracy states, cars, beautiful clothes ("bear furs" are particularly popular here) or dining at expensive restaurants. After all, these are no luxuries at all, but from the point of view of a woman who cannot afford to buy two towels, this does seem like a Hollywood movie life. As such, it is condemned, and rightly punished when the Militia's weight falls on the frauds. But actually, it is hard to completely condemn the perpetrators. It is true that they stole, embezzled and committed fraud, but in the reality of a normal market economy they would have been able to act completely legally, turning their talent into profit for the company.

The crime novels give a clearly negative picture of socialist Poland's economy, which is ineffective and driven by ideology. And ideology has nothing to do with a normal market. In those books, we can find references to the infamous meat and leather scandals. Criminals' modus operandi is also shown. In one book, good quality leather is labeled as the worst quality, and then resold twice - first at a lower price, and then at the highest price. The difference in profit goes straight into the pockets of gang members. Their profit is so large that the director can afford a luxurious house and there is still enough money to pay a dozen or so people involved. A similar procedure was used for meat. What is interesting is the fact that most directors or presidents, feeling that the whole thing would be discovered soon, decide to flee to the West. Sometimes they are caught 
by the Militia and sometimes they end up in the hands of even worse criminals than themselves ("Death and Kowalski").

It is worth mentioning here, that the latter novel was turned into a film, released in 1963 under the title "Ostatni kurs" [The Last Trip] (directed by J. Batory). The film is a vivid and dramatic story of wasteful directors visiting expensive restaurants, drinking luxurious alcohol and committing indecencies - having an affair with a singer from the "Orion" bar. What they do not know is that she is a ruthless boss of a criminal group. In any case, the profit made by frauds is impressive - they have tens of thousands of dollars, which, considering the black market exchange rate at the time, was the equivalent of several million PLN. The sum was staggering compared to the average salary which was around 1500 PLN. This is noteworthy, as it shows what "reserves" were hidden in the state-controlled economy. This kind of money could be made "on the side", but never officially. But, actually, why not? Crime novels and the few crime films showed the economic abnormalities of socialist Poland.

One great example is "The Murder in the Warehouse", a crime play presented as a part of the Kobra Thriller Theater series in 1967. Actually, based on that play, one could teach how the economy socialist Poland was managed. Here, we learn that overemployment, illegal business trips, purchases unnecessary equipment, selling category 1 as category 3 goods (with the difference going into the pockets of the president, the warehouse keeper and the accountant) were the norm. Let us quote a conversation between the president of the warehouse cooperative and the Citizens' Militia captain leading the murder investigation:

Captain: This piece of paper fell on your arm from this puncher.

The president: But this is impossible.

C: Why?

P: Because this paper could not possibly have fallen out of this puncher.

C: So what? It came here by train? You are telling me things about a puncher like a teenage girl.

P: I am not telling you things, I am just saying that it could not have fallen out of this puncher.

C: Why?

P: Because this puncher does not punch. Neither do the others.

C: What do you mean? You sold a whole batch of broken punchers to the Communal Cooperative? Well, someone should be held responsible for that.

P: Well, you see, captain, we gave up the idea of individual responsibility in our warehouse a long time ago.

C: So, who takes responsibility for all these losses?

P: What losses? There are no losses. The warehouse bought punchers and the warehouse sold punchers. 
C: What about the state?

P: Well, the state manufactured flawed punchers, the state sold flawed punchers and the state made money.

C: Leave, leave now!

This dialog explicitly shows the absurdities of the economic system. It also shows how easily scams could be performed. In fact, the situation presented in the conversation with the captain of the Citizens' Militia is nothing short of financial crime, and yet, everything had been operating smoothly until a dead body came up. If it wasn't for that, the business would still be running, involving more and more people. In return for purchasing 500 broken punchers, the supply manager of the Communal Cooperative (GS), Mrs. Łapka, was moved up to no. 4 on the houses rationing list. Legally!

As we can see, crime novels and films showed the mechanism of operation and all the abnormalities of the system in detail. This way, corruption, wastefulness and fraud were condemned. However, no one said openly that these were not specific directors, presidents or supply managers that should have been replaced - but the whole system.

It is also worth adding that many books were inspired by current affairs covered by the press. Many journalists and crime fiction authors got information directly from the Citizens' Militia Headquarters in Warsaw. Back then, its spokesperson was second lieutenant Helena Sekuła, who later started writing crime stories as well. In the 1960s - as she recalled in an interview conducted many years later - she was visited by many journalists and writers who wanted to learn something about investigations, get the latest news or find inspiration. Sekuła mentioned Krzysztof Szmagier (who later became the author of a famous TV series “07 zgłoś się" [Come In, 07], Jacek Wołowski (pen-name of Stanisław Sachnowski, a journalist from "Życie Warszawy") and one of the leading Polish crime authors, Zygmunt Zeydler-Zborowski. She emphasized, though, that they were not the only ones using the information obtained at her department [Lewandowska A. 2006: 298-299].

Interestingly, financial crime was the subject of interest of relatively many female writers - we have already mentioned Kłodzińska, Sekuła, and Gordon here. Gordon wrote e.g. "Klika” [Clique], a novel taking place in the so-called "old" period - the Stalinist times. It is set in the countryside, in a place ruled by a tightly connected group of people holding top positions in the local government. They are also connected with local private businesses. This private-meets-state business turns out to be very lu- 
crative. The same companies keep receiving orders, regardless of the quality of services rendered. Even a young and ambitious party activist cannot handle that and justice only comes with the general transformation, the "thaw", as a result of a journalist investigation. However, not all damage can be repaired - it is impossible to take back the crime that had been committed and covered up.

\section{POLISH CRIME FICTION IN 1960s AND 1970s}

The subject of financial crime, very trendy in the 1960s, was not that exposed anymore in the subsequent decade. In December 1970, Edward Gierek became the new First Secretary of the Polish United Worker' Party Central Committee. The period of his administration is sometimes, somewhat ironically, referred to as La Belle Epoque [Paczkowski A. 2000: 393]. ${ }^{1}$ And it is justified in a way, as his administration is usually considered the best period of socialist Poland history by the people who lived back then. Gierek crack-opened the window to the world, Coca-Cola and Marlboro cigarettes appeared in shops, the automotive industry developed (producing the "small Fiat"), and many films produced in the West were shown on TV. Slowly, salaries grew as well. The situation started to worsen in the middle of the decade - the socialist economy once again turned out to be inefficient, and any real reforms were not possible without the change of the system. However, the way of thinking and the attitude towards consumerism changed. It was not something to be condemned, something characteristic for the western civilization, anymore. The time of the official coarseness was over. There was an informal permission for the members of the party to gain wealth and the slogan of the period was: "Stronger Poland, richer Poles". Gierek himself spoke about it when talking about the construction industry. From what he said, it can be concluded that he was aware of some flaws. He came to conclusion, though, that "a witch hunt made no sense" [Gierek E. 1990: 132-133]. Financial frauds were not investigated as fiercely as in the previous decade, and, naturally, they were not written about as often. The "embezzler" and the "fraudulent director" were not the main characters of crime fiction anymore. They made their great comeback in the 1980s, after the introduction of martial law.

\footnotetext{
${ }^{1}$ This is how he titled the chapter devoted to the 1970s.
} 
This issue is interesting in itself. After December 13, 1981, the publishing market experienced some stagnation. Taking into consideration the four main publishing series specializing in crime fiction: "Dachshund", "Silver key series", "Labyrinth" and "Ewa calls 07" one can see that in 1982, 13 novels were published in total. In 1981, the number was 15, in 1980 - 20 and in, 1979 - 27. Later, the situation returned to normal, although fewer books were published than in the 1970s. The popular comic book series about the adventures of captain Żbik was canceled altogether. The subjects covered were both old and new. Old, because frauds and abnormalities in state companies were mainly written about in the times of the Gomułka administration. New, because they gained a whole new meaning. The previous administration, Gierek's, came under criticism.

After martial law had been introduced, general Wojciech Jaruzelski, the First Secretary of the time, made the decision to bring the people responsible for the crisis that Poland experienced - according to the narrative of the time - to justice. So, Edward Gierek and many of his close coworkers were detained, along with the activists from "Solidarity", [Eisler J. 2014: 306-309]. The trial of Maciej Szczepański, the 1970s head of the state television company and the author of the television "success propagan$\mathrm{da}^{\prime \prime}$, accused of appropriation and fraud, can be considered a show trial [Modrzejewska B. 2015: 13-41]. And this is the picture of the former authorities that started to appear not only in literature, but also in crime films of the 1980s. One can say that crime novel back then was a part of the revisionist policy - of course, a very limited one - towards the previous administration and the former First Secretary. Here, we obviously mean Edward Gierek and his people, not Edward Kania who had briefly occupied the position of the First Secretary before Wojciech Jaruzelski's rise to power. It is during Gierek's administration that the "Solidarity" movement was born, and he was the one to blame for the economic crises and failures.

In crime fiction, the situation was shown so unambiguously that there were no doubts as to the interpretation. People from the previous administration were to blame for frauds. What is more, we find out that they had actually gone unpunished before. Their lifestyles had been unusually lavish, considering the standards of the time. In most cases, this meant having a big house, an expensive car, drinking expensive spirits and spending time in night clubs. Sometimes, there was also a house out of town or a boat to sail in the Mazurian lakes. All in all, all the fraud provided a level of life which in the West was available to the large middle class, while in 
socialist Poland it was available only to the elites. In any case, now, criminals, sometimes related to the local authorities, were finally punished. We can assume that this is owing to the new administration headed by general Jaruzelski. Such is the world depicted e.g. in "Dzwonnik z Friedlandu" [The Bell-ringer from Friendland] (1985) by Krystyn Ziemski; "U Huberta" [At Hubert's] (1982) by Albert Wojt; "Los na loterii" [The Lottery Ticket] (1987) by Andrzej Kakiet, printed in "Echo Krakowa", and "Cocktail nad Zalewem" [Cocktails By the Lake] (1988) by Zofia Kaczorowska.

However, it must be noted that the mechanism of the fraud is not described in detail here. The analysis and the social consequences of the problem are also missing. What was interesting in the writing of Anna Kłodzińska or Barbara Gordon - the grasp of social reality, the psychology of the characters - did not appear in those books anymore. The authors aimed at shocking the readers with bold descriptions of the lavish lifestyle of the elites or how they remained unpunished. Interestingly, it was also the case in films. The film "Smażalnia story" [The Story of the Chip Shop] (1985, directed by Józef Gębski) first takes the viewer to a night club: alcohol is pouring, the club is full of attractive and easy girls, the party is in full swing, as is illegal trade (e.g. in jeans brought from Sweden). Later on, we go to the countryside, where a gang is operating with impunity. The fraud involves a never-ending construction of a chip shop. Both the frauds and the local bosses are pathetic figures, and testify to the the quality of the Gierek period prosperity. This is partly due to the scale of the fraud, which, from the contemporary point of view, seems very innocent. The story ends how it is supposed to end - the Citizens' Militia and the army (as the events take place under the martial law) arrest the criminals. In general, the uniformed forces are always present in the film and their influence on the environment is nothing but soothing.

\section{CONCLUSIONS}

Polish crime novel of the socialist period in Poland is a phenomenon that cannot be ignored. Sometimes criticized for poor literary standards [Barańczak S. 1975; Jastrzębski J. 1982], which is also debatable [Skotarczak D. 2012: 177-188], it remains an interesting historical source nonetheless. It shows the mechanisms of the socialist economy and the types of fraud committed - often referring to current affairs. But it also re- 
mains a unique record of the authorities' attitude towards financial crime and illegal methods of gaining wealth. Industrial espionage is also a recurring theme (e.g. "Tajemniczy obiektyw" [The Mysterious Lens], 1958, by Mikołaj Kozakiewicz; "Będę zamordowana" [I Will Be Murdered], 1970, by Kazimierz Karkozowicz; "Nagła śmierć kibica” [The Sudden Death of the Spectator], 1978, Jerzy Edigey). This particular subject is beyond the scope of this article, but it is worth noting that, as we can read in the novels, foreign intelligence was lying in wait to seize our weaponry or trying to take over our technologies related to the production of plastics.

One might conclude that crime novels provide an interesting and informative vision of the financial aspect of the functioning of socialist Poland. What is also interesting here is the fact that the absurdity of the economic system, which almost encouraged people to commit fraud, is shown - particularly in the period of the "thaw" and in the 1960s - with a surprising frankness.

\section{BIBLIOGRAPHY:}

\section{LITERATURE}

Barańczak. (1975), Polska powieść milicyjna. Dominacja funkcji perswazyjnej a problemy gatunkowe [Polish "Militia novel". Domination of the persuasive function and the problems of the genre] [in:] Stępień M. (ed.), „W kręgu literatury Polski Ludowej” [The literature of socialist Poland], Wydawnictwo Literackie, Kraków, p. 270-316.

Eisler J. (2014), Siedmiu wspaniatych. Poczet pierwszych sekretarzy KC PZPR [The Magnificent Seven. The First Secretaries of the Polish United Workers' Party Central Committee], Wydawnictwo Czerwone i Czarne, Warszawa.

Fik M. (1989), Kultura Polska po Jatcie. Kronika lat 1944-1981 [Polish culture after Yalta. The chronicles of the years 1944-1981], Polonia Book Found LTD, London.

Jarosz D., Pasztor M. (2004), Afera mięsna: fakty i konteksty [The meat swindle: facts and context], Centrum Edukacji Europejskiej, Torun

Jastrzębski J. (1982), Czas relaksu. O literaturze masowej i jej okolicach [Leisure time. About the literature for the masses and its surroundings], Zakład Naukowy im. Ossolińskich, Wrocław.

Leszczyński A. (2000), Sprawy do zatatwienia. Listy do >>Po prostu<<1955-1957 [Things to be done. Letters to the "Po prostu" magazine 1955-1957], Wydawnictwo Trio, Warsaw.

Lewandowska A. (2006), Wywiad z Helena Sekuła [An interview with Helena Sekuła], [in:] Lewandowska A. et al. (ed.), “Druga seta” [The second hundred], Wydawnictwo Mordownia Wielki Sen, Warszawa, p. 298-299.

Modrzejewska B. (2015), Prezesi. Oni rządzili TVP [Presidents. The bosses of the Polish television], The Facto, Warsaw.

Paczkowski A. (1998), Pót wieku dziejów Polski 1939-1998 [Fifty years of Polish history 19391989], Wydawnictwo PWN, Warsaw. 
Rolicki J. (1990), Gierek Edward: Przerwana dekada. Wywiad rzeka, [Gierek, Edward: an interrupted decade. An interview], Wydawnictwo Fakt, Warsaw.

Skotarczak D. (2012), O powieści milicyjnej pozytywnie, [About the "Militia novel" with optimism] [in:] Stańczak-Wiślicz K. (ed.), “Kultura popularna w Polsce w latach 19441989" [Popular culture in Poland in the years 1944-1989], Instytut Badań Literackich PAN, Warsaw, p. 177-188.

Skotarczak D. (2015), Polska powieść kryminalna w okresie odwilży. Próba charakterystyki, [Polish crime novel in the period of the "thaw". A tentative description.] "Literatura Ludowa" [People's literature] no. 6, p. 27-36.

The record of the discussion on the radio about "The Man with the White Eyes" by L. Tyrmand (1956), "Radio i świat" [The radio and the world] no. 18, p. 13.

Dorota Skotarczak - Ph. D is a professor at Adam Mickiewicz University and the head of the Visual History Workshop at the Institute of History at AMU. Her interests include film as a historical source, the history of popular culture and the history of socialist Poland. She is the author of the following books: "Od Astaire'a do Travolty" [From Astraire to Travolta] (1996), "Historia Amerykańskiego musicalu filmowego" [The history of the American musical film] (2002), "Obraz społeczeństwa PRL w komedii filmowej" [The society of socialist Poland in comedy film] (2004), "Historia wizualna" [Visual history] (2012, 2013), "Z problematyki przemian kultury polskiej w XX wieku" [The problems of Polish cultural transformation in the $20^{\text {th }}$ century] (ed. 2000) Media wizualne w warsztacie historyka" [Visual media in the work of a historian] (ed. 2008), "Społeczeństwo PRL. Historia" [Society in socialist Poland. The history](2011), “Okno na przeszłość. Szkice z historii wizualnej" [The window to the past. Sketches in visual history] (2015), "Społeczeństwo PRL. Kultura. Pamięć" [The society in socialist Poland. Culture. Memory] (2015), "Sport w PRL" [Sports in socialist Poland] (2015). 